\title{
University studies as a side job: causes and consequences of massive student employment in Estonia
}

\author{
Maarja Beerkens $\cdot$ Eve Mägi $\cdot$ Liis Lill
}

Published online: 28 July 2010

(C) The Author(s) 2010. This article is published with open access at Springerlink.com

\begin{abstract}
Student employment is increasingly common in many countries. Compared to earlier decades, not only more students work but they also work longer hours. Among European countries Estonia is one of the clear "leaders" in student employment. This study uses survey data from 2,496 students in Estonian public and private universities to examine the reasons for working on such a massive scale and its consequences on academic success. The results show that, unlike in most other countries, Estonian students from more privileged families are as likely to work as students from poorer families and they are even more likely to have a full-time job. Furthermore, working seems to have only a marginal negative effect on academic progress. These results seem to support the theory that in Eastern European countries student employment has become a signal of students' capabilities and ambition, and that relatively low academic standards contribute to the strength of the signaling mechanism. A long-term solution to student employment would require changes in quality standards, student financing, alternative higher education opportunities, and perceptions of students, employers, and academics.
\end{abstract}

Keywords Employment - Academic progress - Student funding · Access · Higher education - Estonia

M. Beerkens ( $\square)$

CHEPS, University of Twente, PO Box 217, 7500AE Enschede, The Netherlands e-mail: m.soo@utwente.nl

E. Mägi

PRAXIS Center for Policy Studies, Estonia pst 5a, Tallinn 10143, Estonia

e-mail: eve@praxis.ee

L. Lill

Department of Economics, University of Tartu, Narva mnt 4, A315, Tartu 51009, Estonia e-mail: liis.timmusk@ut.ee 


\section{Introduction}

Most countries in the Western world experience an increase in student employment. Nowadays more students have a paid job during their studies and students tend to work longer hours. A recent Europe-wide student survey shows that in some countries more than two-thirds of students are employed and income from employment covers up to $80 \%$ of living and study costs (HIS 2008). On average, the student employment rate is around $47 \%$ in Europe. The situation is not different in other parts of the world. In the United States the number of employed students has consistently increased and reaches now $49 \%$ of students in the 4-year universities (US Department of Labor 2007). In Australia, an increasing trend has led to almost 50\% of employment (ABS 2009).

Several reasons explain why students nowadays work more. The financial aspect of working tends to receive most of the attention. Increasing costs of higher education and changes in the funding system in many countries make jobs necessary for covering the costs (e.g. Watts and Pickering 2000; Brennan et al. 2005). Furthermore, changes in the expected lifestyle and consumption preferences of students create a need for additional resources (Penman and McNeill 2008). On the other hand, structural changes in the economy, in higher education and in student profiles encourage student employment (Darmody and Smyth 2008). Growing economies (at least before the recent crisis) made more part-time jobs available and employers may reach out to the relatively flexible and low-paid labor force with a good learning potential and positive attitude (Barke et al. 2000; van der Meer and Mielers 2001; Curtis and Lucas 2001). Also, the profile of university students has changed. Higher education is now more open to "non-traditional" students, such as mature students and students from lower socio-economic groups, who tend to be more inclined to work during their studies (Pascarella and Terenzini 1998). As a final point, universities may now provide more flexible study opportunities that make a combination of work and study more feasible.

Employment patterns among students are an important policy issue for two main reasons. First, student employment may be a sign of a weak financial aid system. If financial means from other sources, such as family resources, stipends, and student loans are lacking, then earnings from a paid employment may be the only option to be able to cover study costs. This may indicate a problem of access to higher education. Secondly, there may be a negative correlation between time spent on working and time invested into studying. An excessive work load of students may compromise their academic progress. Less study time is associated with lower learning outcomes and a higher probability of dropping out of school. Moreover, research suggests that a valuable contribution to student development is made not only in the classroom but also through interaction with academic staff and peers outside of the classroom (Pascarella and Terenzini 1998; Kuh 1995). Long hours of working outside of the university may threaten this kind of interaction. If students are forced to work because of limited financial resources, we would expect that students from less affluent families are particularly affected by these negative effects on their academic development. Furthermore, a prolonged study time and a high drop-out rate is wasteful from the perspective of social costs and the costs of individual students.

This paper examines employment patterns in a country where most employment related figures are at the upper margin. In Estonia two-thirds $(66 \%)$ of students have a paid job during their studies; they work on average $20 \mathrm{~h}$ a week; and wages cover $60 \%$ of their total income (HIS 2008; Eurostat 2009). In this paper we will examine two key questions: Is student employment driven by financial needs? And if not, why do students 
work on such a massive scale? And secondly, does working affect their academic progress? Before answering the questions, we examine research evidence from other countries about the relationship between term-time employment, student background, and academic progress.

\section{Research evidence about employed students}

Research about term-time employment among students, especially in the United States, United Kingdom, and Australia, is quite extensive. There seem to be some patterns that are common to most countries that have been studied. Not only student employment is becoming more and more common over time, it is more common among specific student groups. In general, students from less affluent families are more likely to work (e.g. Barke et al. 2000). Kalenkoski and Pabilonia (2008) find a direct correlation between lower financial contribution from the family and more hours of employment. This suggests that student employment is primarily a way to compensate lacking family resources. In terms of other background characteristics, female students tend to work more, and there is some evidence that mature students work slightly more (Brennan et al. 2005; Darmody and Smyth 2008).

Lack of financial resources, however, is not the only possible motivator for employment. Students may work also for more positive reasons. Employment may provide necessary work experience that will be rewarded by the labor market after graduation. It may also contribute to building a social network that will help find a job in the future. Several studies have found that college employment in the US has a positive effect on the labor market outcomes, such as wage, occupational status and likelihood of employment (Light 2001). Term-time employment may be good also for personal development because it advances an understanding of the business world and leads to increased confidence and social skills (Curtis and Shani 2002). Others are somewhat skeptical about the positive effects, arguing that a self-selection bias among working vs non-working students explains most of the variance (Hotz et al. 2002).

A crucial question about student employment is its effect on academic progress. There is overwhelming evidence that working during university studies has a negative effect on students' grades, academic progress, and retention (DeSimone 2008; Brennan et al. 2005; Stinebrickner and Stinebrickner 2003; Kalenkoski and Pabilonia 2008). The effect of student employment is, however, more nuanced than this broad generalization. First of all, the effect seems to be non-linear. Students who are employed less than $8 \mathrm{~h}$ have been found to be unaffected (Berg 2002) or perform even better academically (Hood et al. 1992) than their fellow students who do not work at all. Furthermore, it is not only the number of hours but also the type of work that matters. Students who work off-campus seem to be affected negatively while students with on-campus jobs are either unaffected or even positively affected (Ehrenberg and Sherman 1987; Astin 1975). Finally, some suggest that the effect is also dependent on when during their study program students work. Kohen et al. (1978) find that working during the first 2 years has a negative effect on academic progress while the effect disappears in the later years.

In sum, international evidence on working students seems to suggest some generalizations. Students work more than in earlier times; students from less affluent families are more likely to work; and working affects study progress, but the effect depends on the number of hours worked, the type of work, and when during the studies students work. 


\section{Estonia in a comparative perspective}

In the last 15 years enrolment in higher education has grown rapidly in Estonia. Three times as many students entered higher education in 2008 as in 1993 (HTM 2009). Currently about $65 \%$ of upper secondary school graduates continue their studies in a higher education institution immediately in the following year (HTM 2009). As a rough estimate of the gross enrolment rate, about $35 \%$ of young people receive a higher education degree. Unlike in many other countries, there is no clear target for increasing higher education participation any further. Low interest in some specific fields, however, is seen as a problem and government has put in place initiatives to attract more students to the science and engineering fields and to balance the overwhelming preference for social sciences and humanities.

The higher education sector in Estonia consists in three types of institutions: universities, professional higher education institutions and vocational education schools. In total Estonia has 34 higher education institutions, both public and private. There are nine public universities, two of which are specialized in arts and music and one, a former Academy of Agriculture, in life sciences. The public universities educate about two-thirds of all students. Private universities are relatively small (below 3,000 students) and offer programs only in limited fields. While in the 1990s the number of private institutions skyrocketed, the market has currently stabilized at around 16 private institutions.

Estonia has a double fee structure, which is a common model in the Eastern European countries. Higher education is free, but only for a small number of selected students. There is a limit on the number of state funded places in each field and each university. Statefunded places are allocated to students competitively, based on their academic performance. Students whose achievements at the standardized national tests and university entrance examinations are not sufficient must pay a tuition fee if they wish to continue their studies. Currently $46 \%$ of students study on state funded places and the rest pay a tuition fee (HTM 2009). The government target is to ensure free access to higher education to $50 \%$ of high school graduates. The state funded places can be allocated to both public and private institutions but in reality the private sector holds only a very small proportion of these places.

To cover the living and study costs all full-time students have access to a student loan. The loan is provided by commercial banks, but government offers some guarantees. Additional need-based support to students is virtually non-existent. A small proportion of students in state funded places receive a monthly allowance, but this grant is also based primarily on academic performance. Students in acute need can get help through the general social welfare system. This structure of student funding has given to Estonia the last place among European countries with respect to need-based financial assistance. In fact, according to the Eurostudent data Estonia together with Slovenia are the only countries where students from well-off families get more support from the government than students from a lower socio-economic group (HIS 2008, p93).

From the student employment perspective, not only financial needs but also economic opportunities matter. Until the crises of 2009 Estonian economy was growing very well. The economic growth rate in 2005-2007 was between 7 and 10\% and the unemployment rate was only around 5-6\% (EP 2010; Stat 2010). There has been a growth in jobs particularly in the service sector. Having a higher education degree brings clear advantages in terms of employment and income level. Highly educated people have lower unemployment rate and higher average salaries (Stat 2010). 


\section{Data and study sample}

This study is based on data from the Survey of Students' Socio-Economic Situation, conducted in 2008 by PRAXIS Center for Policy Studies on behalf of the Federation of Estonian Student Unions. The survey questionnaire inquired about personal and family background, current study situation, living conditions, funding, employment, and several other aspects. The dataset includes a usable response from 2,496 students from 24 higher education institutions (public and private, and academic, professional and vocational institutions). The sample includes students at the Bachelor and Master level but excludes $\mathrm{PhD}$ students. The survey included both full-time and part-time students, but in this study we analyze only full-time students. Part-time students tend to have a different employment patterns and also different reasons and problems associated with working. It should be noted that the proportion of part-time students is very low in Estonia.

The main characteristics of our sample can be seen in the "Appendix" (Table A1). The sample seems to be representative of the overall population of students in Estonia with respect to the main characteristics. There is a minor sampling error in terms of the school type (public university, private university, vocational higher education institution) and gender. These biases are corrected with appropriate sampling weights.

The socio-economic background of students is one of the main explanatory variables in this paper. Unfortunately data on family income is quite problematic in the survey. One question asked students to indicate the range of their parents' monthly income. This question has a lot of missing values and unreasonable estimates, which makes the information useless. Instead we use a softer and more subjective measure of family resourcesa student's evaluation of the economic well-being of his or her family (on a 1-3 scale).

Another complicated variable is the ethnic background. Estonia has a large Russian speaking minority that consists not only of Russians but also of Ukrainians, Belarusians and other ethnic groups. The minority group is distinctive not only in terms of the first language but also in terms of socio-economic indicators. The Russian-speaking community has a higher unemployment rate and lower average income. Because of these labor market effects it is important to include ethnic background as a control variable in our study on employment patterns. There are several ways to operationalize this dimension, such as selfreported ethnicity, language spoken at home, or the mother tongue. All these measures are imperfect because of mixed families and multiple identities of students. We will use the language of instruction in the secondary school as the measure of ethnic background. Since we use the ethnic background primarily as a control variable for academic progress and employment patterns, it is primarily the comfort level with the Estonian language and integration with the Estonian community that is relevant, and we believe that secondary school is a strong socialization environment for future students.

The sample has one major weakness from the point of view of the study design. The survey is distributed among students, which means that people who have dropped out of school are not represented in the sample. This may include also students who have dropped out because they have not been able to combine successfully their work and studies. This potential bias should be kept in mind when interpreting the results. The drop-out statistics, however, shows that the bias is probably not very severe. The drop-out rate in Estonia is relatively low compared to many other countries-17.9\% at the Bachelor level and $17.1 \%$ at the Master level in 2007/2008 (HTM 2010). About a quarter of these students drop out during their first year and the largest proportion, 39\%, have been in school 4 years or longer (Must 2006). The minimum requirements that students must fill in order to keep their student status are relatively soft. 
The paper uses multivariate logistic regression analysis in order to explore the simultaneous impact of different factors on student employment and academic success. We will examine three hypotheses:

- Student employment is higher among students from a lower socio-economic group;

- Student employment is associated with financial needs of students;

- Student employment has a negative effect on academic progress.

\section{The extent of student employment}

As we saw above, term-time employment is extremely wide-spread among Estonian students. According to our sample, $61 \%$ of full-time students work. The analysis shows that the most important predictor for working is the age. Older students (over 23 years) are more than three times as likely to have paid jobs as younger students (Table 1). A further analysis shows that not only many students work but a high proportion of our full-time students has a full-time job. Among the age group of 23 years and younger, 35\% students work part-time and $17 \%$ work full-time. In the age group of 24 years and above, $19 \%$ work part-time and $64 \%$ work full-time. It is thus clear that when students become older they are more likely to have jobs and they work more on full-time jobs. This is an indication of two parallel processes. Students do not wait until they finish their studies before they enter the labor market. Rapidly expanding economy and shortage of skilled workers makes students attractive for employers even before their studies are finished, and lucrative labor market conditions allure students to accept the jobs. Secondly, students who return to school in later years, either to start higher education or to obtain a second degree, are unlikely to give up their jobs.

In addition to the age, students at the Master level and in applied higher education institutions are more likely to work (Table 1). Also students who must pay a tuition fee are significantly more likely to work than students on state-funded places. Their probability to work increases by $14.5 \%$. The maximum limit of student loans in Estonia does not cover the tuition and living costs, which means that tuition-paying students are forced to find

Table 1 Likelihood to work, logistical regression

\begin{tabular}{lclll}
\hline Variable & Coefficient & $\begin{array}{l}\text { Standard } \\
\text { deviation }\end{array}$ & $\begin{array}{l}\text { Odds } \\
\text { ratio }\end{array}$ & $\begin{array}{l}\text { Marginal } \\
\text { effects }\end{array}$ \\
\hline Mature age (over 23) & 1.283 & 0.130 & 3.444 & $0.272 * * *$ \\
Male & 0.102 & 0.093 & 1.131 & 0.024 \\
Estonian (language of & -0.123 & 0.129 & 0.896 & -0.029 \\
$\quad$ instruction) & & & & \\
Parents' subsistence level & 0.042 & 0.095 & 1.046 & -0.010 \\
Father's higher education & -0.121 & 0.104 & 0.871 & -0.029 \\
Tuition & 0.629 & 0.083 & 1.788 & $0.145^{* * *}$ \\
Applied university sector & 0.718 & 0.218 & 2.003 & $0.160 * * *$ \\
Postgraduate & 0.585 & 0.226 & 1.732 & $0.128^{* * *}$ \\
Constant & -0.340 & 0.304 & 3.444 & $-/-$ \\
$N=2,496$ & & & & \\
Chi-square (df=)307*** & & & & \\
Pseudo R-square =0.092 & & & & \\
\hline
\end{tabular}


Table 2 Sources of income and employment patterns by family income a Income from study loan and study allowance is omitted due to a low quality of the data $* * * p<0.01$
Family is Family has Family is Chiwell-off sufficient financially square income constrained

\begin{tabular}{lllll}
\hline $\begin{array}{l}\text { Income sources }(E E K)^{\mathrm{a}} \\
\text { Parents' contribution }\end{array}$ & 2,089 & 1,484 & 1,021 & \\
Grants & 338 & 225 & 200 & \\
$\begin{array}{l}\text { Net income from } \\
\quad \text { employment }\end{array}$ & 5,300 & 5,248 & 4,621 & \\
$\begin{array}{l}\text { Other sources } \\
\text { Employment }\end{array}$ & 1,416 & 1,185 & 1,070 & \\
$\begin{array}{l}\text { Part-time employment } \\
\text { Full-time employment }\end{array}$ & $29 \%$ & $31 \%$ & $32 \%$ & \\
$\begin{array}{l}\text { Employment under 24 } \\
\text { Part-time employment }\end{array}$ & $33 \%$ & $30 \%$ & $28 \%$ & \\
$\begin{array}{l}\text { Full-time employment } \\
\text { Reasons for working }\end{array}$ & $21 \%$ & $17 \%$ & $14 \%$ & \\
Professional work & $47 \%$ & $41 \%$ & $31 \%$ & $15.8^{* * * *}$ \\
$\quad$ experience & & & & \\
General work experience & $54 \%$ & $43 \%$ & $35 \%$ & $22.5^{* * * *}$ \\
$\begin{array}{l}\text { Fill spare time } \\
\text { Subsistence }\end{array}$ & $24 \%$ & $15 \%$ & $10 \%$ & $22.5^{* * * *}$ \\
Extra income & $42 \%$ & $62 \%$ & $77 \%$ & $135^{* * * *}$ \\
\hline
\end{tabular}

other income sources if their family does not cover all the costs. Contrary to the evidence from other countries, personal background characteristics do not seem to be influential. Not only is there no relationship with gender and the ethnic background of students, also the financial means of the family and the educational background of parents do not seem to have an effect. ${ }^{1}$ This result raises a question of whether working is a matter of necessity for financial reasons, as often assumed, or whether it is a choice driven by other factors.

When we explore how Estonian students cover their study costs, then there are only small differences between students from a well-off family and students from a family whose resources are very limited. The data demonstrates the obvious: students from betteroff families receive more money from their parents (Table 2). ${ }^{2}$ Students from less affluent families compensate lower parental contributions either with study loans or cope with less money. The proportion of students that takes study loans decreases with the income status of their parents: while $66 \%$ of students with low family income take student loans, $58 \%$ from mid-income families, and $47 \%$ from higher income families take study loans. Income

\footnotetext{
${ }^{1}$ The effect of the socio-economic status can be observed indirectly. Students in the applied university sector tend to come from lower socio-economic groups. Some of the effect of the university sector is thus likely to mediate the effect of the socio-economic status. When the applied university sector is omitted from the model, both parent's income and father's education have a negative effect on the probability of working.

${ }^{2}$ Data on student income sources is quite ambiguous, with many missing values and unrealistic estimations, suggesting perhaps that students themselves do not have a clear overview of their money sources or that their income stream is volatile.
} 
from working, however, does not seem to be a way to compensate limited family funds. Income from employment is the same for all students, regardless of their family background.

Interestingly, students from well-off families are more likely to work full-time. While part-time employment rate among young students ( $\leq 23$ years) is around $35 \%( \pm 2 \%)$ for all three income groups, the full-time employment rate varies from $14 \%$ for the lowest income group, $17 \%$ for the middle group, up to $21 \%$ for the highest income group. Among older age group this difference disappears. Full-time employment thus seems to be a choice rather than a necessity. Probably students from well-off families have a better social network and thus better opportunities for finding a fulfilling job. Other students cannot find similar opportunities as easily and therefore do not work or do only part-time work for necessity. This leads us to examining the reasons why students work.

\section{Motives for student employment}

There are multiple possible reasons why students work, as described earlier, and the reasons may vary between different student groups. Our data shows that the less means a family has, the more likely it is that a student works in order to be able to support himself or herself (Table 2). While $77 \%$ of students from the low income group mention that they work for subsistence, only $62 \%$ of the middle group and $42 \%$ of the upper group report this as a reason. Students from more affluent families are more likely to work for extra income and for general and professional work experience. Students from higher income families are also more likely to work to fill spare time, but this reason is the least common among all income groups. It should be noted that the questionnaire item did not ask students to identify one most important reason for work but all relevant reasons. It appears that students from higher income group tend to identify more reasons for working, which indicates that they are less likely to have one dominant reason. It can be therefore concluded that many students do not work in order to support themselves, but in order to get some experience, some additional money to spend, or on some other reasons.

\section{The effect of student employment on academic progress}

Working is not a problem by itself, especially when students are not forced to work in order to be able to support their studies. When working interferes with academic responsibilities, however, then it may have negative consequences on the future of individual students as well as the higher education system as a whole.

Our data confirms the evidence from international research that working has a negative effect on academic progress, but in Estonia the effect seems to be very small. Surveyed students were asked to report if they are on schedule to graduate in the nominal time. The results show that employed students are only $5 \%$ less likely to graduate in the nominal time (Table 3). This means that students sacrifice their academic success to some extent when they choose to work. Besides working, we can see that male students and mature students have a bigger danger of staying behind. Family background also seems to matter. Students from better-off families are more confident about their progress. This may be a result of the additional sense of certainty that these students have. They have the option to quit their jobs, if needed, and finish. Students from the applied higher education sector are also less likely to stay behind which probably refers to better structured curricula in these schools. 
Table 3 Likelihood of graduating within nominal time, logistical regression

\begin{tabular}{|c|c|c|c|c|c|c|}
\hline \multirow[t]{2}{*}{ Variable } & \multicolumn{3}{|c|}{ Unspecified employment $\mathrm{h}$} & \multicolumn{3}{|c|}{ Specified employment $\mathrm{h}$} \\
\hline & Coeff. & St. dev. & $\begin{array}{l}\text { Marginal } \\
\text { effects }\end{array}$ & Coeff. & St. dev. & $\begin{array}{l}\text { Marginal } \\
\text { effects }\end{array}$ \\
\hline Employed & -0.289 & 0.106 & $-0.050 * * *$ & & & \\
\hline 8 or less $\mathrm{h}$ & & & & 0.131 & 0.286 & 0.022 \\
\hline $9-25 \mathrm{~h}$ & & & & 0.013 & 0.139 & 0.002 \\
\hline More than $25 \mathrm{~h}$ & & & & -0.303 & 0.116 & $-0.055^{* * *}$ \\
\hline Male & -0.391 & 0.105 & $-0.072 * * *$ & -0.392 & 0.105 & $-0.072 * * *$ \\
\hline Mature (age over 23) & -0.540 & 0.112 & $-0.101 * * *$ & -0.516 & 0.114 & $-0.097 * * *$ \\
\hline Estonian (language of instruction) & -0.232 & 0.177 & -0.039 & -0.243 & 0.178 & -0.040 \\
\hline Parents' income level & 0.189 & 0.079 & $0.033^{* *}$ & 0.181 & 0.079 & $0.032 * *$ \\
\hline Father's higher education & -0.320 & 0.106 & $-0.058 * * *$ & -0.333 & 0.107 & $-0.061 * * *$ \\
\hline Applied university sector & 0.513 & 0.118 & $0.085 * * *$ & 0.515 & 0.118 & $0.085 * * *$ \\
\hline Postgraduate & -0.206 & 0.154 & -0.038 & -0.214 & 0.154 & -0.039 \\
\hline \multirow[t]{2}{*}{ Constant } & 1.454 & 0.235 & $-1-$ & 1.413 & 0.236 & $-1-$ \\
\hline & \multicolumn{3}{|c|}{$\begin{array}{l}N=2,496 \\
\text { Chi-square }(\mathrm{df}=) 94.00^{* * *} \\
\text { Pseudo R-square }=0.034\end{array}$} & \multicolumn{3}{|c|}{$\begin{array}{l}N=2,496 \\
\text { Chi-square(df=)95.34*** } \\
\text { Pseudo R-square }=0.035\end{array}$} \\
\hline
\end{tabular}

$* * * p<0.01, * * p<0.05$

While employment slows down students slightly, it does not damage at all the motivation to graduate. The students were asked whether they intended to finish their studies. The answers of employed students were not systematically different from unemployed students. If anything, they seem to be rather more determined to finish ("Appendix" Table A2). When we look at the personal characteristics, male students and Estonian students are less sure about their finishing; mature students, master students, and students from affluent families are more determined to finish.

The data also confirms that the negative effect of working on academic progress is not linear. Working under $8 \mathrm{~h}$ a week, and even under $25 \mathrm{~h}$ a week, has no significant effect on the academic progress (Table 3, specified employment hours). Only students who work more than $25 \mathrm{~h}$ start to compromise their academic work. The problem in Estonia is thus not students with part-time jobs but students who have close to full-time employment. A correlation analysis shows that on average each additional hour that a student spends on an employment reduces the hours spent on studies by $13 \min (r=-0.22, p=0.000)$.

In sum, there is a relationship between having a job and succeeding academically. Students who choose to work more than $25 \mathrm{~h}$ a week experience that their academic work starts to suffer. Compared to other countries, however, the effect is relatively small. This raises a question of how can Estonian students combine their work and studies so successfully.

\section{Discussion and conclusions}

Estonia has an extremely high employment rate among the student population. It is tempting to draw parallels with other countries and conclude that working is necessitated by financial constraints and that the financial aid system needs to be changed. Our statistical analysis, however, does not confirm these generalizations and it presents quite surprising results about employed students in Estonia. The expected relationship between the socio-economic 
background of a student and likelihood to work is not supported; neither can we confirm the hypothesis that employed students seriously sacrifice their academic progress. Our evidence tells the following story. Most students indeed work in order to support themselves. At the same time, students from more affluent families are not less likely to work than students from poorer families, and they are even more likely to have full-time jobs. One could argue that students in Estonia are seen as financially independent from their parents and therefore the economic background of their family is irrelevant for their employment-related decisions. However, this does not seem to be a correct argument because according to our evidence students from affluent families do receive more money from their parents. If employment would be driven primarily by financial reasons we could expect to see some correlation between family background and employment. This seems to suggest that the extraordinarily high employment rate is not entirely due to problems with the financial aid system and working does not seem to be an absolute necessity for many students.

A parallel story line concerns the relationship between employment and academic progress. Our literature review demonstrated that term-time employment tends to have serious consequences on academic progress. Interestingly enough, employment has only at best a marginal effect on academic progress in Estonia, even though a great proportion of students work even full time. This means that either Estonian students are incredibly efficient, capable and hardworking in combing jobs and studies, or university studies are not particularly demanding. Internationally comparative data from the Eurostudent survey shows that the number of hours that Estonian students spend on their studies is the lowest in Europe-about $25 \mathrm{~h}$ per week (HIS 2008). This raises some concerns about the quality of education. Even when students progress and eventually graduate next to their (almost) full-time jobs, is their education sufficiently good with such a limited time investment?

These curious patterns encourage us to search for a new explanatory framework which would reach beyond the common assumptions about the financial needs. Our results seem to comply with a theory that in East European countries working during studies perhaps should be seen as a signaling mechanism. Yudkevich and Apokin (2009) have developed a theoretical econometric model that explains student employment in Russia and links employment with low academic standards. They describe a chain of events that explains a picture quite similar to Estonia. They argue that the standards in Russian higher education are not very high. On the one hand, this is linked to the transition problems from the Soviet past. Labor market has gone through a major transformation and the new needs are not fully incorporated in universities' curricula. More importantly, however, universities are short of money, which makes them economize on education and maximize the number of fee-paying students. It is in the interest of the university to avoid students dropping out. Higher education is therefore not very demanding. As a result, more ambitious and capable students search for a challenge and additional learning opportunities through a part-time (or full-time) employment. Also employers know that university education is not very demanding and academic achievement is not enough of a signal for productivity. Termtime employment has therefore become a signal of productivity and motivation. The problematic part of the chain is the fact that there is no force in the system that would make universities increase their standards over time. It should be emphasized that a university diploma is still valued by employers, especially as an additional signal of ambition, and most attractive jobs by definition expect a higher education degree. Low standards do not reduce the demand for the higher degree. However, there is no demand for high quality education because employers are not able to evaluate its quality and reward it accordingly. Universities, on the other hand, are highly dependent on students for their income and they must keep the costs low, and therefore there is no incentive to raise the standards. 
What could be done in a situation like this? Lessons from other countries suggest two sets of interventions to deal with excessive student employment: set up restrictions on employment so that students are not allowed to work or improve the financial aid policy so that students do not need to work. It is not uncommon in the United States to have a limit on how many hours per week students are allowed to work, especially in their first year of studies and out of campus. This restriction may be linked to their financial aid package or on-campus job opportunities. Such restrictions would not solve the problem in Estonia. Working seems to be rather a symptom of underlying problems, not the cause of the problems. At a European level it has been shown that non-employed students spend only slightly more time on their studies (HIS 2008). All students face the same academic expectations. If the standards are low then also non-employed students are not encouraged to invest more time into their studies. Furthermore, such restrictions punish students who cannot cover the study and living costs without employment.

The relationship between employment and financial aid is particularly raised in the UK. The increasing costs of higher education in recent years have not been in balance with the possible financial aid and therefore push students to find a job (Watts and Pickering 2000; Brennan et al. 2005). This has triggered discussions about an optimal aid package. According to the results of this study, changes in the financial aid system in Estonia would have only a limited effect. Some changes in the financial aid policy may help to alleviate the problem. Currently a full fee paying student in Estonia cannot cover all expenses from a student loan and grants. Unless the family can support the student, he or she has no other option than to work. But as we saw earlier, having family resources does not really decrease the inclination to work.

The structural problem seems to be the fact that with such a low time investment Estonian students can progress academically and graduate. The core problem is thus low expectations in universities. Unless the expectations and demands from students increase, students continue to invest more time into their paid work than into their studies. Universities thus have a key role in raising the standards. Interestingly, only in recent months the issue of low standards in Estonian higher education has been brought up in the biggest daily newspaper (e.g. Simson 2010; Laks 2010). However, universities are dealing with their own problems related to cost-efficiency and heavy dependence on fee-paying students. And many fee-paying students would not be willing or able to continue their studies if they could not work at the same time. The problem is caused by a well-known weakness of markets in higher education. In the higher education sector, quality and cost-efficiency of education can be ensured through a market only if there is transparent information about learning outcomes (see Dill and Soo 2004). Measuring quality of education and learning outcomes is a great challenge in higher education.

Massive student employment in Estonia is thus part of a chain and every link in the chain needs attention to reach a long-term solution. The problem seems to require a systematic approach and different instruments. Currently opportunities for part-time studies are very limited in Estonia. Creating an effective system for part-time students would help some students (who on some reason need to have a full-time job) structure their studies in a better way. Secondly, the quality assurance system should offer right incentives for universities to raise their standards. Estonia has an effective quality assurance system. Regular program level assessments by international evaluators and mandatory accreditation monitors that the conditions for high quality education are ensured. Perhaps more attention would be needed on instruments that encourage universities to monitor students' learning outcomes and seek a constant improvement. Instruments such as Academic Audits (see e.g. Massy 2010) would be a good combination of respecting universities' autonomy but encouraging universities to take responsibility for students' learning. The role of 
financial aid policy is to ensure that no student group, neither state-funded nor fee-paying, are forced to work excessively on financial reasons. The most important change, however, depends on attitudes. When employers reward academic achievement then students have an incentive to devote more to their studies, only then universities have an incentive to offer higher quality education, and this again would make employers reward academic achievement. Cutting through this chain process seems to be a challenge for many East European countries and perhaps also in some other parts of the world.

Open Access This article is distributed under the terms of the Creative Commons Attribution Noncommercial License which permits any noncommercial use, distribution, and reproduction in any medium, provided the original author(s) and source are credited.

\section{Appendix}

See Tables 4, 5.

Table 4 Key characteristics of the sample

\begin{tabular}{|c|c|}
\hline & All \\
\hline \multicolumn{2}{|l|}{ Gender } \\
\hline Male & 1,775 \\
\hline Female & 721 \\
\hline \multicolumn{2}{|l|}{ Age } \\
\hline$\leq 23$ & 1,810 \\
\hline$>23$ & 686 \\
\hline \multicolumn{2}{|l|}{ Ethnic background } \\
\hline $\begin{array}{l}\text { Estonian as the language of instruction in the secondary } \\
\text { school }\end{array}$ & 2,270 \\
\hline Russian as the language of instruction in the secondary school & 226 \\
\hline \multicolumn{2}{|l|}{ Parents' economic affluence } \\
\hline Low & 452 \\
\hline Middle & 1,524 \\
\hline High & 520 \\
\hline \multicolumn{2}{|l|}{ Father's education } \\
\hline Higher education & 1,736 \\
\hline Below higher education & 760 \\
\hline \multicolumn{2}{|l|}{ Tuition } \\
\hline Tuition exempt & 1,543 \\
\hline Fee paying & 953 \\
\hline \multicolumn{2}{|l|}{ Employment } \\
\hline Employed & 1,528 \\
\hline Not employed & 948 \\
\hline \multicolumn{2}{|l|}{ Sector } \\
\hline University & 1,778 \\
\hline University of applied sciences & 718 \\
\hline \multicolumn{2}{|l|}{ Postgraduate } \\
\hline Bachelor & 2,235 \\
\hline Above bachelor & 261 \\
\hline TOTAL & 2,496 \\
\hline
\end{tabular}


Table 5 Students' intention to finish their studies, ordered logit

The question: "Do you intend to finish your studies?" Answers:

$1=$ yes, 2 = probably yes,

$3=$ indecisive, $4=$ probably no,

$5=$ no

\begin{tabular}{lcll}
\hline Variable & Coefficient & $\begin{array}{c}\text { Standard } \\
\text { deviation }\end{array}$ & Odds ratio \\
\hline Employed & -0.106 & 0.103 & 0.900 \\
Male & $0.300^{* * * *}$ & 0.104 & 1.350 \\
Mature (age over 23) & $-0.407 * * *$ & 0.121 & 0.666 \\
Estonian (language of instruction) & $0.798^{* * *}$ & 0.208 & 2.221 \\
Parents' subsistence level & $-0.176^{* *}$ & 0.080 & 0.839 \\
Father's higher education & 0.086 & 0.111 & 0.918 \\
Applied university sector & 0.159 & 0.109 & 1.173 \\
Postgraduate & $-0.353^{*}$ & 0.197 & 0.702 \\
Constant & & & \\
$N=2,496$ & & & \\
Chi-square(df=)55*** & & & \\
Pseudo R-square $=0.014$ & & & \\
\hline
\end{tabular}

\section{References}

ABS, Australian Bureau of Statistics. (2009). Education and work, Australia. http://www.abs.gov.au. Accessed 20 Dec 2009.

Apokin, A., \& Yudkevich, M. (2009). Reasons for student employment: education signaling upside down. HSE Working Paper. http://www.hse.ru/data/699/145/1235/Apokin_Yudkevich2008.pdf. Accessed 20 Dec 2009.

Astin, A. W. (1975). Preventing students from dropping out. San Francisco: JosseyBass.

Barke, M., Braidford, P., Houston, M., Hunt, A., Lincoln, I., Morphet, C., et al. (2000). Students in the labour market: Nature, extent and implications of term-time working among university of Northumbria undergraduates. Nottingham: DfEE.

Brennan, J., Callender, C., Duaso, A., Little, B., Van Dyke, R. (2005). Survey of higher education students' attitudes to debt and term-time working and their impact on attainment. A report to Universities UK and HEFCE by CHERI and London South Bank University. http://www.universitiesuk.ac.uk/Publications/ Documents/termtime_work.pdf. Accessed 20 Dec 2009.

Curtis, S., \& Lucas, R. (2001). A coincidence of needs? Employers and full-time students. Employee Relations, 23(1), 38-54.

Curtis, S., \& Shani, N. (2002). The effect of taking paid employment during term-time on students' academic studies. Journal of Further and Higher Education, 26(2), 129-38.

Darmody, M., \& Smyth, E. (2008). Full-time students? Term-time employment among higher education students in Ireland. Journal of Education and Work, 21(4), 349-362.

DeSimone, J. S. (2008). The impact of employment during school on college student academic performance. NBER Working Paper No. 14006.

Dill, D., \& Soo, M. (2004). Transparency and quality in higher education markets. In D. Dill, B. Jongbloed, \& P. Teixeira (Eds.), Markets on higher education-mature economies. Dordrech: Kluwer Academic Publishers.

Ehrenberg, R. G., \& Sherman, D. R. (1987). Employment while in college, academic achievement, and postcollege outcomes: A summary of results. Journal of Human Resources, 22(1), 152-164.

EP-Bank of Estonia. (2010). Eesti majandusnäitajad aastate lõikes. http://www.bankofestonia.info/pub/et/ dokumendid/statistika/. Accessed 20 Jan 2010.

Eurostat. (2009). The Bologna process in higher education in Europe: Key indicators on the social dimension and mobility. Luxembourg: Office for Official Publications of the European Communities.

HIS-Hochschul Informations System. (2008). Social and economic conditions of student life in Europe: Synopsis of indicators, Final report, Eurostudent III 2005-2008. Hannover: Hochschul Informations System, Socrates and Bundesministerium für Bildung und Forschung.

Hood, A. B., Craig, A. F., \& Ferguson, B. W. (1992). The impact of athletics, part-time employment and other activities on academic achievement. Journal of College Student Development, 33(September), $447-453$. 
Hotz, V. J., Xu, L. C., Tienda, M., \& Ahituv, A. (2002). Are there returns to the wages of young men from working while in school? The Review of Economics and Statistics, 84(2), 221-236.

HTM. (2009). Statistiline ülevaade kõrghariduse õppekavadel õppijate näitajatest, Riikliku koolitustellimuse komisjonile, K. Klooster (Ed). Tartu: HTM. http://www.hm.ee/index.php?popup=download\&id=8925. Accessed 20 Jan 2010.

HTM. (2010). Kõrghariduse valdkonna koondnäitajad, Tabel F4. http://www.hm.ee. Accessed 06 June 2010.

Kalenkoski, C. M., \& Pabilonia, S. W. (2008). Parental transfers, student achievement, and the labor supply of college students. U.S. Bureau of Labor Statistics Working Paper No 416.

Kohen, A., Nestel, G., \& Karmas, C. (1978). Factors affecting individual persistence rates in undergraduate college programs. American Educational Research Journal, 15(2), 233-252.

Kuh, G. D. (1995). The other curriculum: Out-of-class experiences associated with student learning and personal development. Journal of Higher Education, 66(2), 123-155.

Laks, L. (2010) Eesti ülikool: ei jõua, ei viitsi. Eesti Päevaleht, 21.05.2010.

Light, A. (2001). In-school work experience and the returns to schooling. Journal of Labor Economics, 19(1), 65-93.

Massy, W. F. (2010). Education quality audit as applied in Hong Kong. In D. D. Dill \& M. Beerkens (Eds.), Public policy for academic quality: Analyses of innovative policy instruments. Dordrecht: Springer.

Meer, P., \& van der Mielers, R. (2001). The increased labour market participation of Dutch students. Work, Employment and Society, 15(1), 55-71.

Must, O. (2006). Mittenormatiivse õpiedu asjaolud ja motivatsioon: Uurimuse aruanne. Tartu Ülikool. http://www.hm.ee/index.php?popup=download\&id=4910.

Pascarella, E. T., \& Terenzini, P. T. (1998). Studying college students in the 21st century: Meeting new challenges. The Review of Higher Education, 21(2), 151-165.

Penman, S., \& McNeill, L. S. (2008). Spending their way to adulthood: Consumption outside the nest. Young Consumers, 9(3), 155-169.

Simson, P. (2010) Amatöörina tippu ei jõua. Eesti Päevaleht, 21.06.2010.

Stat-Statistikaamet. (2010). Aastastatistika. http://pub.stat.ee/px-web.2001/Database/Sotsiaalelu/15TOOT URG/15TOOTURG.asp. Accessed 20 Jan 2010.

Stinebrickner, R., \& Stinebrickner, T. R. (2003). Working during school and academic performance. Journal of Labor Economics, 21(2), 473-492.

U.S. Department of Labor. (2007). College enrollment and work activity of 2006 high school graduates. News release. Washington, DC: Bureau of Labor Statistics. http://www.bls.gov/news.release/hsgec.nr0. htm. Accessed 20 Dec 2009.

van den Berg, M. N. (2002). Studeren? (G)een punt! Een kwantitatieve studie naar studievoortgang in het Nederlandse wetenschappelijk onderwijs in de periode 1996-2000. Rotterdam: EUR (proefschrift).

Watts, C., \& Pickering, A. (2000). Pay as you learn: student employment and academic progress. Education + Training, 42(3), 129-135. 